\begin{tabular}{ll}
\hline \hline MINING AND METALLURGY INSTITUTE BOR & ISSN: 2334-8836 (Štampano izdanje) \\
UDK: 622 & ISSN: 2406-1395 (Online) \\
\hline \hline
\end{tabular}

Vesna M. Marjanović, Aleksandra T. Ivanović*

\title{
SELECTION THE STABILIZATION/SOLIDIFICATION PROCESS AND SELECTION THE BINDERS AND REAGENTS DEPENDING ON THE TYPE OF WASTE MATERIAL IN THE FUNCTION OF ENVIRONMENTAL PROTECTION**
}

\begin{abstract}
This paper presents the overview and method of selection the stabilization/solidification process, considering that a very long time suitable for treatment the hazardous waste in order to protect the environment. Selection the method for stabilization/solidification $(S / S)$ the hazardous waste depends on the type of waste, content of hazardous and harmful components and it is applied as the method of pretreatment the hazardous waste before disposal into landfill. Also, in this paper, the data are systemized that related to the process of stabilization and solidification, the basic concepts relating to these processes, as well as the phase of collecting the information on processing and verification the process $S / S$.

This paper provides the possibilities of selection the additives depending on the type of waste material. Using the technological process of stabilization/solidification $(S / S)$ and corresponding additives, the waste material is transformed into inert material independently of the individual values of metal solubility or components in waste. Also the fact of great importance is that some physical or chemical parameters of solidified waste material (permeability, resistance to compression) can be easily controlled by selection of chemical additive and its share in the mixture (wasteladditives). The process of $S / S$ has a reasonable use in liquid waste or waste with a high content of liquid phase with impossible disposal on the landfills without prior treatment.

These processes can be performed in-situ - on the location of hazardous waste and ex-situ - in the facilities that are designed for that purpose.

Keywords: stabilization/solidification, environmental protection, hazardous waste, additives
\end{abstract}

\section{INTRODUCTION}

Stabilization/solidification processes have been in use since 1950, when they were applied for the treatment of radioactive and hazardous waste. Today, these processes and technologies are used for treatment and remediation of contaminated soil and waste originated from the technological processes of metals, purification of drinking water and others.

Stabilization/solidification $(\mathrm{S} / \mathrm{S})$ process is used to remove a wide range of pollutants from different materials and contaminated waste, particularly those contaminated with substances classified as "dangerous". The treatment involves mixing a binding agent with medium or contaminated waste [1].

The treatment involves mixing a binding agent with medium or contaminated waste, so the hazardous substances contained in it are immobilized and their mobilization in the environment is prevented [2].

\footnotetext{
*Mining and Metallurgy Institute Bor

** This work is the result of the Project TR 33038: Improvement the Technology of Exploitation and Processing of Copper Ore with Monitoring the Environment in RTB Bor Group, funded by the Ministry of Education, Science and Technological Development of the Republic of Serbia.
} 
Stabilization and solidification are processes which include a wide range of technologies, which closely related to the chemical and/or physical processes of reduction the potential negative impacts on the environment (soil, surface and ground water) and indirectly on the wildlife and human health [2].

\section{CONCEPT OF STABILIZATION AND SOLIDIFICATION}

Stabilization refers to the techniques for reduction the potential hazards of waste and transforms the pollutants into less soluble, mobile, or toxic form using the chemical processes. The physical characteristics of waste have not to be changed in the course of stabilization.

Solidification refers to the techniques that encapsulate the waste, forming a solid material, and doing so there are no chemical interactions between the pollutants and additives used for fixing. Solidification is achieved by a chemical reaction between the waste and specific reagents or mechanical processes. The product of waste solidification may be a monolithic block, clay-like material, granular particles, or another other physical form that is usually considered a "solid substance".

Solidification is divided into the microencapsulation (particles up to $2 \mathrm{~mm}$ ) and macro-encapsulation (particles larger than 2 $\mathrm{mm}$ ), depending on the grain size distribution of material to be treated [3]. Migration of impurities is often limited by reduction the surface area exposed to the leaching and/or coating material waste with small permeability.

The combined processes of solidification /stabilization mixed waste, soil and sludge, and treatment by the certain agents constitute the hazardous ingredients in them physically and chemically fixed. These technologies are not considered as the destructive techniques, but they just eliminate or prevent (complicate) the mobility of pollutants [3].

Stabilization and solidification processes cover a wide range of technologies, which are closely associated with chemical and/or physical processes to reduce the potential negative impacts on the environment (soil, surface and groundwater) and indirectly on the wildlife and human health (ITRC). The $\mathrm{S} / \mathrm{S}$ is an important technological process which allows transforming of wastes into inert material, regardless the value of individual solubility of metals, or the components in the waste. Also, the fact is of great importance that some physical or chemical parameters of solidified waste material (permeability, resistance to compression) can easily control the selection of chemical additives and their share in the mixture (waste/additives) [4].

\section{SELECTION THE STABILIZATION/SOLIDIFICATION PROCESS DEPENDING ON THE TYPE OF WASTE MATERIAL}

Selection process is primarily dependent on the type of waste material and its further treatment. Based on the type of waste is the identification of S/S technology as the Best Demonstrated Available Treatment Technology - BDAT, and Figure 1 shows the phase of collecting the information on technological process, and Figure 2 shows the manner in which the technological checking of stabilization/solidification process is carried out [5].

Based on the preliminary characterization, it is necessary to perform the waste sampling, after which it is necessary to do the additional characterization on the basis of which it is decided whether the waste is acceptable for laboratory research or not. If so, a detailed characterization of waste is carried out, then the physical, chemical and microstructural testing the $\mathrm{S} / \mathrm{S}$ waste, and based on this information the facility characteristics are given, in the ex-situ case of $\mathrm{S} / \mathrm{S}$, Figure 1, [5].

Checking the technology of the S/S process in-situ begins studying the characteristics of terrain and waste, and field sampling. After that, setting the performance targets, and then it is needed to 
develop a feasibility study in which it is decided whether the process $\mathrm{S} / \mathrm{S}$ is aviable option. If the answer is no, it is needed to check whether the best analytical and technical solutions are selec-ted, and if the answer is negative again, the conclusion is made that the process $\mathrm{S} / \mathrm{S}$ would be unsuccessful.

When the feasibility study produces

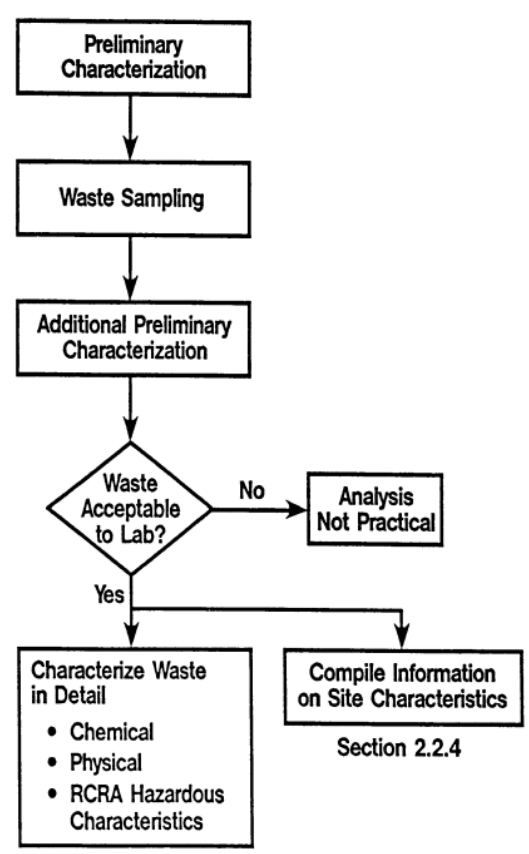

Figure 1 Information collection steps in the technology-screening process [5]

\section{SELECTION OF ADDITIVES ACCORDING TO THE TYPE OF WASTE}

Selection the S/S method of hazardous waste depends on the type of waste, content of hazardous and harmful components, and is applied as a method of pre-treatment of hazardous waste before disposal to a landfill.

A large influence on the efficiency of the process has a selection of additives used in the process of $\mathrm{S} / \mathrm{S}$, which depend on the the positive results, the literature is checked to select the best combination of waste/binder, and laboratory analyses and testing. In the case of positive test results, testing in the site or pilot plant is carried out based on which a positive or negative decision will be made on the process of $\mathrm{S} / \mathrm{S}$ waste materials, Figure 2 [5].

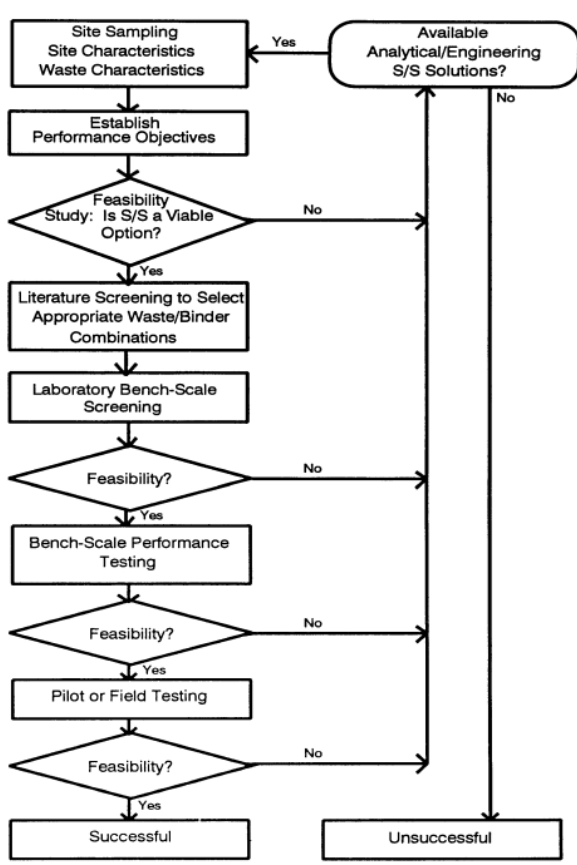

Figure 2 Solidification/stabilization technology screening [5]

type of waste and conditions of aging the product of $\mathrm{S} / \mathrm{S}$ process. The efficiency of the $\mathrm{S} / \mathrm{S}$ process is done by determining the mobility of hazardous and harmful components, and compressive strength, after the solidification/stabilization process.

Additives which are used as binders in the processes $\mathrm{S} / \mathrm{S}$ can be of inorganic and organic origin or a combination thereof. The 
most commonly applied additives are of inorganic origin such as: cement, ash, lime, soluble silicates, pozzolans, bentonite, clays, blast furnace slag and other materials, and the organic additives are asphalt, epoxide, polyester and polyethylene. Inorganic binders are used in more than $90 \%$ of the process $\mathrm{S} / \mathrm{S}$. In general, inorganic binders are cheaper and easier to use than organic. Organic binders are generally used for solidification of radioactive waste or specific volatile organic compounds [6].

\subsection{Inorganic binders as additives}

In order to facilitate the selection of additives, depending on the type of waste, the paper of the authors Fleri M. A., et al., (2007) [7] provides an overview of additives used in the processes of S/S. Based on the results obtained by the analytical methods of processing a sample and criteria to be met by the S/S waste material, a preliminary selection of additives is carried out.

The most commonly used additive is Portland cement $(P C)$, which can meet a variety of physical and chemical conditions [8] (ASTM C150, 2003). During testing, the Portland cement is usually combined with other reagents to form a mixture that meets the required criteria. The additives of primary importance are pozzolans, bentonite and chemicals that reduce leaching and dilution of pollutants.
Pozzolans are supplements that contain fly ash, silica fumes and other fine-ground cement substances that increase the strength, density and durability. In the field of environmental protection is commonly used pozzolana including fly ash and slag from blast furnaces. The ashes can be classified into two main classes, as specified in the standard ASTM C618 [9].

Another significant pozzolan is the blast furnace slag, which is defined as a "nonmetallic product that is essentially composed of silicate, alumino-silicates and calcium base that is developed in a molten condition simultaneously with iron in a blast furnace." Three types of slag used in production cement, and they are air-cooled, expanded and granulated slag. The main feature of these types of slag is durability and use as an addcement product. Due to its affordability and accessibility, blast furnace slag is selected for use in a mixture with fly ash [7].

\subsection{Efficiency of additives for different types of waste material}

The success of the process of S/S primarily depends on the selection of additives and their efficiency. Table 1 shows the additives that are commonly used and their application depending on the type of waste material.

Table 1 Recommended process of S/S depending on type of waste [4]

\begin{tabular}{|l|l|}
\hline \multicolumn{1}{|c|}{ Process of S/S } & \multicolumn{1}{c|}{ Application } \\
\hline Solidification with cement & Sludges, contaminated land \\
\hline Solidification with lime & $\begin{array}{l}\text { Waste from the desulfurization of waste gases, } \\
\text { other inorganic waste }\end{array}$ \\
\hline Solidification with thermoplastic materials & Radioactive waste \\
\hline Encapsulation & Sludges, liquids \\
\hline Vitrification & Extremely hazardous waste, radioactive waste \\
\hline
\end{tabular}

In such cases, it is efficient use of cement as an additive for binding the liquid phase, because the cement reacts with water, chemically binding the water in e hydrated cement product. Free liquid phase when adding cement binds it more often chemical bonds, and less is absorbed, and therefore the resistance to compression of at least $0.34 \mathrm{MPa}$ (50 psi) [4]. 
In the case of implementation the remediation process as the sustainability process of land, S/S is often the only solution and the available technology for remediation of large amounts of soil contaminated with heavy metals, sludge or sediment. In this case, the cement is recommended, because it reduces the mobility of metal ions, forming a hardly soluble metal hydroxide, carbonate or silicate. During the process of $\mathrm{S} / \mathrm{S}$, metal transforms from ionic forms into mineral structure and physical encapsulation. Also, pre-treatment can reduce the toxicity of some metals changing the valence state [4].

Applying the combined process of stabilization and solidification of waste containing heavy metals, the transformation of form of the heavy metals occurs to a large degree and they usually transform into heavy soluble hydroxides in which the mobility of heavy metal ions is reduced.

Solidification further reduces the mobility of heavy metals from the newly created heavy soluble forms, Figure 3.

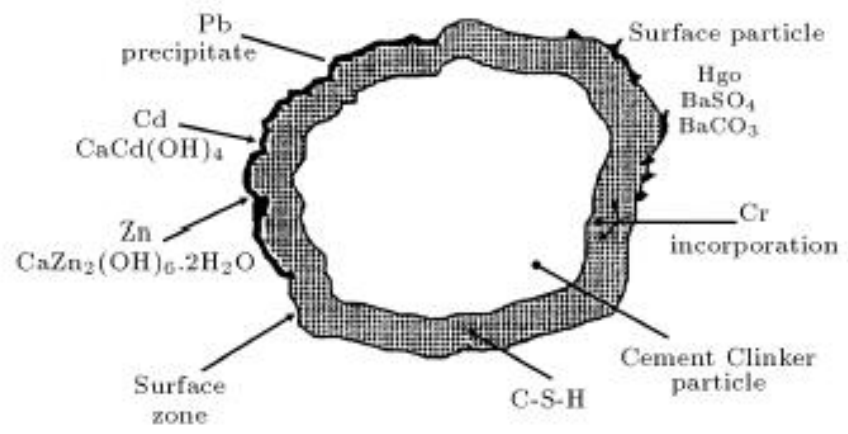

Figure 3 Solidification and stabilization of heavy metals by hydrates of Portland cement [11]

Treatment of materials containing mostly organic pollutants is also possible using the cement as an additive. In the process of $\mathrm{S} / \mathrm{S}$, the material hardening occurs through changes in physical properties of cement. They are highly recommended if the waste or material contains free water, which enters in the hydration process, producing with cement high physically integrated material monolith. The process has demonstrated a high efficiency in reducing the mobility of hazardous and harmful substances from waste containing semi volatile and heavy volatile polycyclic aromatic hydrocarbons (PAHs), polychlorinated biphenyls (PCBs), pesticides, organic cyanides and others.

Disadvantage of S/S applying of cement is in the cases when the waste has a high content of fats and oils, when the process of cement hydration is disabled. The cement particles are coated with oils or fats, thus inhibiting a contact between cement and water. Some organic components affecting the binding time of cement, thus the whole process of solidification can be extended considerably. For these reasons, it is necessary before selection of additives to carry out a complete qualitative and quantitative chemical analysis of waste, thereby preventing the adverse effects on the ground. Also, using the quicklime, as additive, results into an exothermic reaction during the hydration process and thereby liberating a significant amount of energy. If the waste includes volatile hazardous and harmful components, the same, during the S/S, will to be emitted into the atmosphere. If there is no other alternative to quicklime as an additive in the process of $\mathrm{S} / \mathrm{S}$, it is necessary to provide the facilities for collection and treatment of gases/air [4]. 


\subsection{Selection of additives, depending on the type of waste}

In order to facilitate the selection of additives depending on type of waste, the investigation were carried out by the author Chan B. K. C. et al. (2008) [14]. Tested materials for development a model for selection of additives were as follows: JR -waste with higher levels of hazardous components, OMW - fine-grained, Fe- and Ca-rich neu tralization precipitates from bioleaching with relatively low levels of hazardous components. Tested additives are: SS - silica sand, PC - commercially available cement, FA fly ash and L - lime. Table 2 shows the test results of stabilization the hazardous waste with different content of harmful components using different additives and with different proportions.

Table 2 Material formulation for CLSM mix design [12]

\begin{tabular}{|c|c|c|c|c|c|c|c|}
\hline \multirow{2}{*}{ MIX } & \multicolumn{6}{|c|}{ Dry solids/\% } & \multirow{2}{*}{$\begin{array}{c}\text { Ratio of water to } \\
\text { solid }\end{array}$} \\
\hline & PC & FA & SS & OMW & JR & $\mathbf{L}$ & \\
\hline 5PC-FA & 5 & 15 & 80 & - & - & - & 0.20 \\
\hline 5PC-FA-OMW & 5 & 15 & 70 & 10 & - & - & 0.30 \\
\hline 5PC-FA-JR & 5 & 15 & 70 & - & 10 & - & 0.25 \\
\hline 10PC-FA-JR & 10 & 15 & 65 & - & 10 & - & 0.30 \\
\hline 10L-FA-JR & - & 15 & 65 & - & 10 & 10 & 0.43 \\
\hline 5PC-FA-L-JR & 5 & 15 & 65 & - & 10 & 5 & 0.41 \\
\hline
\end{tabular}

$J R$ - with higher levels od hazardous components, OMW - fine-grained, $\mathrm{Fe}$ - and Ca-rich neutralization precipitates from bioleaching with relatively low levels of hazardous components, SS - silica sand, $P C$ - a commercially available cement, $F A$-fly ash and L - lime.

Concentrations of heavy elements As, $\mathrm{Cd}, \mathrm{Co}, \mathrm{Cu}, \mathrm{Mn}, \mathrm{Mo}$ and $\mathrm{Ni}$ in waste after pretreatment, obtained by implementation of the prescribed test procedures of hazardous and toxic waste characteristics, were below the allowable values for groundwater and soil, even from the waste samples with increased content of hazardous components. Figure 4 shows the concentration of $\mathrm{Pb}$ and $\mathrm{Zn}$ from various additives, and with which it can be seen that the concentrations of $\mathrm{Pb}$ and $\mathrm{Zn}$, with a combination of additive 5PC-5L-JR are above the intervention value. In tested sample JR, the concentrations of $\mathrm{Pb}$ and $\mathrm{Zn}$ were above the allowable limit. Testing of contaminated soil with a lower content of hazardous components, and after the procedure of pretreatment, gave the satisfactory results [12].
Adsorption on hydrated iron (III) oxide, which was present in samples has reduced the mobility of arsenic, Figure 5.

\subsection{Correct selection of reagents}

For the stabilization of waste containing heavy metals and a large amount of water, which was a result of mining activities, the process recommended lime neutralization of creation the hardly soluble hydroxide in alkaline conditions.

Further, in the process of solidification can occur on the grain surface, in the presence of silicon and aluminum, a liquid barrier, calcium silicate gel, or calcium-aluminate gel, thereby increasing the efficiency of the process [13]. Curve hydroxide solubility of heavy metals, depending on the $\mathrm{pH}$ of the environment, is illustrated in Figure 6 (a), which clearly shows the influence of $\mathrm{pH}$ value on mobility of heavy metals [4]. 

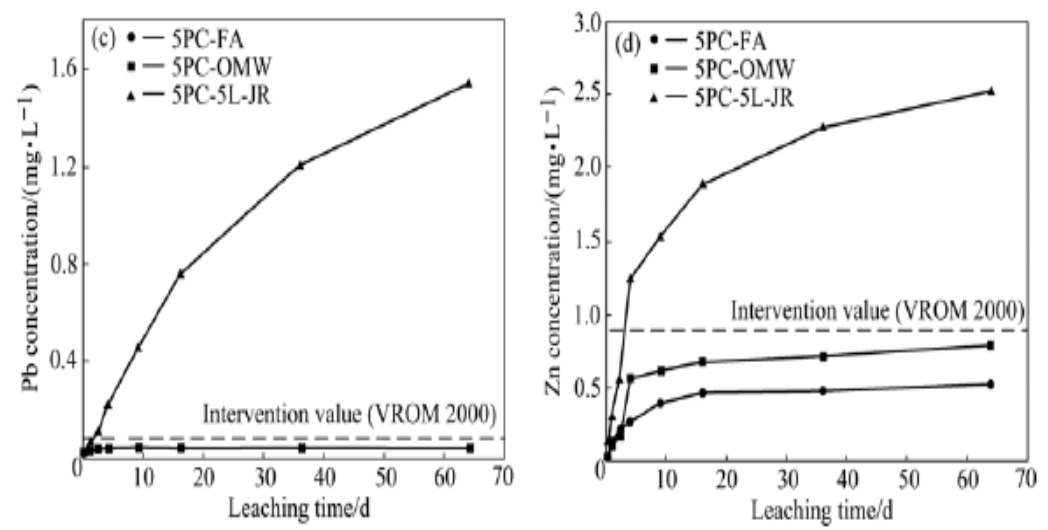

Figure $4 \mathrm{~Pb}$ and As concentrations with the addition of various additives [12]

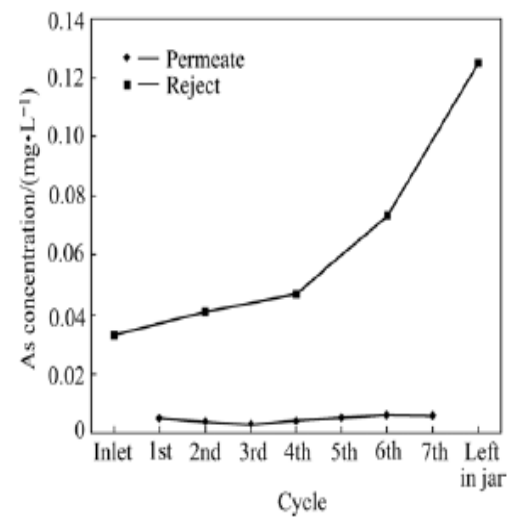

Figure 5 Concentration of arsenic with and without the addition of additives $\left(\mathrm{Fe}_{2} \mathrm{O}_{3}\right)$ to the initial concentration As of $0.03 \mathrm{mg} / \mathrm{L}$ [12]

Treatment of the resulting product after the solidification process and stabilization of waste material can have a significant effect on the efficiency of process.

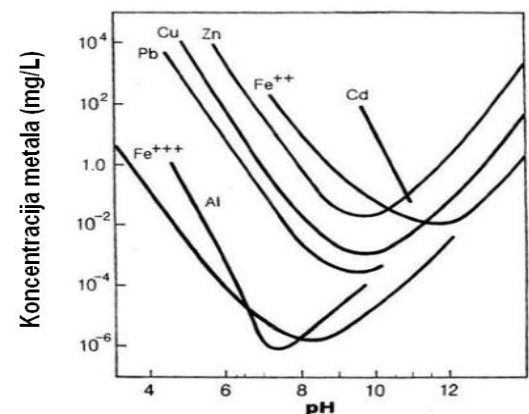

(a)
Figure 6 (b) shows the effect of temperature and drying conditions and aging time on the mobility of zinc ions in the sludge.

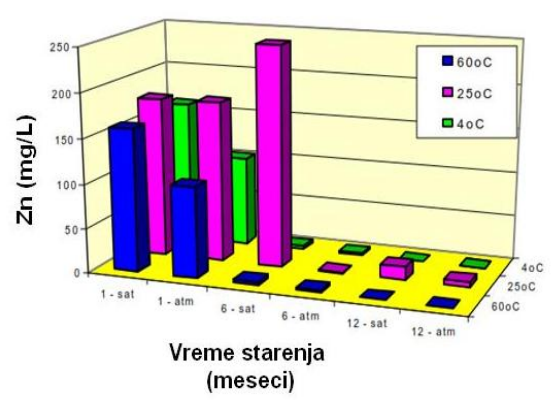

(b)

Figure 6 (a) Solubility curve of heavy metal hydroxide depending on the $p H$ and (b) The effect of temperature, drying conditions and aging time on the mobility of zinc ions in the sludge [4] 
Figure 6 clearly shows that the aging of 6 months at temperature of $25^{\circ} \mathrm{C}$, at atmospheric conditions, reduces the mobility of zinc to less than $10 \mathrm{mg} / \mathrm{L}$, [4].

\section{PROCESSES OF STABILIZATION/SOLIDIFICATION IN-SITU AND EX-SITU}

Processes and technology of stabilization /solidification in-situ are popular for treatment and remediation of contaminated soil, particularly at the location where the buildings already exist or are abandoned. The process of $\mathrm{S} / \mathrm{S}$ contributes to the sustainable development such as the contaminated material can be treated in site and thus reused without fuel consumption for transport and reduction the risk to the environment [1].

In-situ stabilization/solidification or deep soil mixing is a widely accepted technique in the field of environmental protection, which is used for immobilization of pollutants, thus preventing further spreading of pollution through the soil and groundwater. $\mathrm{S} / \mathrm{S}$ is used for the ecological treatment of various industrial waste materials from contaminated sites. In any case, the treated material can be reused in-situ or at another location, which significantly reduces costs and protects the human health and environment [1].

The most common in-situ stabilization process involves mixing the contaminated soil or waste with cement as additive or other materials that have similar chemical and physical properties (fly ash, etc.) that have a high adsorption capacity, thus reducing the mobility of hazardous and harmful components [14].

Processes S / S used for remediation are intended to reduce the passage of pollutants from soil, sediment, sludge and waste that is washed (leach) from a source of pollution to the environment, within the acceptable criteria listed in order of remediation.

Technology S/S can be applied for a wide range of pollutants. The successful implementation of this technology begins with the testing locations. Subsequently, on the basis of the collected data, the treatability study (TS) and pilot studies (PS) are performed which show the required amount and impact of binders on soil as well as the soil geochemistry. To determine the potential efficiency of the S/S technology, the parameters should be collected that related to the tests and criteria used for development of the $\mathrm{S} / \mathrm{S}$ treatment that meets the objectives of the remediation. These specifications are intended to: (1) guidance and evaluation the feasibility studies and (2) establishing a minimum number of field operations and compliance the characteristics of material in the laboratory conditions. Improving the technology - the project $\mathrm{S} / \mathrm{S}$ is done by monitoring the life cycle of process, from the research of site to the completion of remediation, as the evidence of technology sustainability. Well done the feasibility study might reduce the number and type of additives to be used in the pilot study, which also allows a correct pricing, delivery and availability of additives and binders, as well as to better understand the physical and chemical properties of the contaminated waste. The selection of additives and binders must be carried out systematically on the basis of physical and chemical properties of the waste, and then based on the best supplier of additives and most widespread and most cost effective binder because the additive costs can amount to $30-50 \%$ of the stabilization costs [7].

When the remediation is implemented - realized, the long-term natural resource management programs are needed that are typically used to check whether the project is still in effect, and as such whether it protects the human health and the environment (ITRC).

Fleri M.A. et al. (2007) showed a number of projects in which the technologies of stabilization involving injecting a binding agent into the soil. In fact, the technology of deep mixing of soil beco- 
ming a common choice of remediation technologies, Figure 7, because it reduces the amount of excavated soil (off-site), and thus saving the benefits and costs of removal and subsequent filling; reduces unpleasant smells while performing remediation and

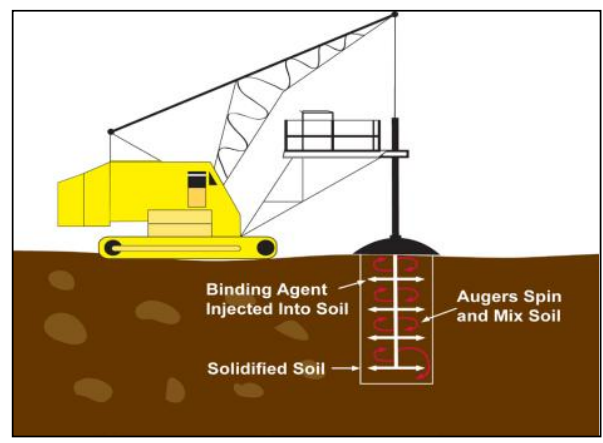

(a) the total remediation costs are significantly lower than the other remediation technologies such as the thermal desorption and insitu chemical oxidation for removal of contaminated materials.

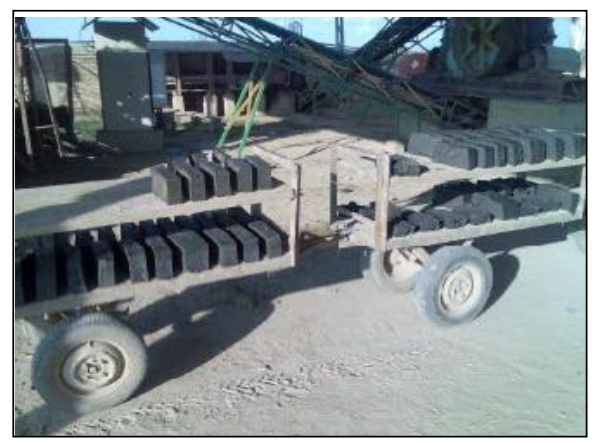

(b)

Figure 7 S/S process in-situ (a) and ex-situ ( $S / S$ waste material) (b)

The S/S ex-situ processes are applied in plants that have been designed for these processes and are used for different types of sludge and other waste materials containing "hazardous" substances, such as heavy metals; the $\mathrm{S} / \mathrm{S}$ waste material is shown in Figure 7[17].

\section{CONCLUSION}

In the process of stabilization/solidification ( $\mathrm{S} / \mathrm{S})$ has been proven to be effective for the treatment of waste containing dangerous substances. The most important step in the process of $\mathrm{S} / \mathrm{S}$ waste material represents a qualitative and quantitative analysis of waste material, based on which it can make a choice of binder and additives.

Physical and chemical methods are carried out tests with $\mathrm{S} / \mathrm{S}$ products, on the basis of which is made of his categorization. By changing the physical character of waste using stabilization/solidification process, prevent the occurrence of a large amounts of leachate at the landfill with a high content of hazardous and harmful components; thus achieving a double effect, protects the envi- ronment on the one hand and on the other hand reduces the process costs of hazardous waste disposal because there is no need for the installation and operation the system for waste/leachate water from the landfill.

\section{REFERENCES}

[1] Wilk C. M. (A), Applying Solidification/Stabilization for Sustainable Redevelopment of Contaminated Property [Internet]. LEHP, QEP, LEED AP Program Manager, Waste Treatment Portland Cement Association; http://www.pollutionengineering.com/ ext/resources/PE/Home/Files/PDFs/PC A_S-S_Whitepaper.pdf?1354286601

[2] ITRC, [Internet]. Washington: Interstate Technology \& Regulatory Council, http://www.itrcweb.org/ Team/Public? teamID $=15$

[3] EPA, 1999., [Internet]. Solidification/stabilization resource guide, EPA/542-B-99-002 (1999), http://epa.gov/tio/download/remed/soli dstab.pdf 
[4] Zinck J., [Internet]. Canada: Review of Disposal, Repro-Cessing and Reuse Options for Acidic Drainage Treatment Sludge, The Mining Association of Canada, MEND and CENMET Mining and Mineral Scienties Laboratories, MEND Report 3. 42. 3, 2005: 3, http://mend-nedem.org/wp-content/ uploads/2013/01/3.42.3.pdf

[5] EPA 1993., [Internet]. Technical Resource Document, Solidification/Stabilization and its Application to Waste Materials, June 1993, p. 1-5. p. 2-6. (A), p. 2-2. (B)

[6] EPA, 2000., [Internet]. Solidification/ Stabilization Use of Superfund Sites, EPA-542-R-00-010, Septembar 2000, http://www.epa.gov/tio/download/rem ed/ss_sfund.pdf

[7] Fleri M. A., Whetstone G. T., In situ stabilisation/solidification: Project lifecycle, J. Hazard. Mater. 2007; 141: 441-456.

[8] ASTM C150, Standard Specification for Portland Cement, vol. 4.01, American Society for Testing Materials, West Conshohocken, Pennsylvania, 2003, pp. 150- 153.

[9] ASTM C618, Standard Test Method for Coal Fly Ash and Raw or Calcined Natural Pozzolan for Use in Concrete, vol. 4.02, American Society for Testing Materials, West Conshohocken, Pennsylvania, 2003, pp. 319-321.

[10] Black Hills Bentonite, LLC. 2009., [Internet]. Wyoming, http://www.bhbentonite.com/minchar. htm
[11] Ganjidoust H., Hassani A., Rajabpour Ashkiki, Cement-Based Solidification/Stabilization of Heavy Metal Contaminated Soils with the Objective of Achieving High Compressive Strength for the Final Matrix, Sharif University of Technology, Transaction A: Civil Engineering, 2009; 16: 107-115, http://www.sid.ir/en/VEWSSID/J_pdf/ 95520092A05.pdf

[12] Chan B. K. C., Bouzalakos S., Dudeney A. W. L., Integrated Waste and Water Management in Mining and Metallurgical Industries, Trans. Nonferrous Met. Soc. China. 2008; 18: 1497-1505

[13] Bakstrom M. Baltic Sea Region Programe, Orebro University, Sweden: Compendium of Mining and Processing Waste Management Technologies, Project: MINNOVATION Mining and Mineral Processing Waste Management Innovation Network, Baltic Sea Region Programe, 2013: 214, http://www.minnovation.eu/uploads/ compendium $\% 20$ of\%20Mining \%20 and $\% 20$ Processing $\% 20 \mathrm{Waste} \% 20 \mathrm{Man}$ agement\%20Technologies.pdf

[14] Gardić V., Obradović Lj., Filipović S., Review of Solidification and Stabilization Methods of Hazardous Waste, MME Bor. 2013; 4: 93-100.

[15] Krčmar D., Stabilization/Solidification of Sludge Rich with Arsenic. http://www.arsenicplatform.pmf.uns.ac .rs/pdf/10_Solidifikacija.pdf 


\begin{tabular}{ll}
\hline \hline INSTITUT ZA RUDARSTVO I METALURGIJU BOR & ISSN: 2334-8836 (Štampano izdanje) \\
UDK: 622 & ISSN: 2406-1395 (Online) \\
\hline \hline
\end{tabular}

Vesna M. Marjanović, Aleksandra T. Ivanovic ${ }^{*}$

\section{IZBOR PROCESA STABILIZACIJE/SOLIDIFIKACIJE I IZBOR VEZIVNIH SREDSTVA I REAGENASA U ZAVISNOSTI OD VRSTE OTPADNOG MATERIJALA U FUNKCIJI ZAŠTITI ŽIVOTNE SREDINE**}

\section{Izvod}

U radu je dat pregled $i$ način izbora procesa stabilizacije/solidifikacije s obzirom da se veoma dugo upotrebljavaju za tretman opasnog otpada u cilju zaštite životne sredine. Izbor metode stabilizacije/solidifikacije (S/S) opasnog otpada zavisi od vrste otpada, sadržaja opasnih $i$ štetnih komponenti, $i$ primenjuje se kao metoda predtretmana opasnog otpada pre odlaganja na deponiju. Takođe, ovom radu sistematizovani su podaci vezani za procese stabilizacije i solidifikacije, osnovni pojmovi koji se odnose na ove procese, kao i faze prikupljanja informacija o tehnološkom procesu i provera procesa $S / S$.

U radu su date mogućnosti izbora aditiva u zavisnosti od vrste otpadnog materijala. Primenom tehnološkog postupka stabilizacije/solidifikacije (S/S) i odgovarajućih aditiva otpadni materijal se transformiše u inertni materijal nezavisno od pojedinačnih vrednosti rastvorljivosti metala, odnosno komponente u otpadu. Takođe, od velike je važnosti činjenica da se neki fizički ili hemijski parametari solidifikovanog otpadnog materijala (propustljivost, otpor na kompresiju) mogu lako kontrolisati izborom hemijskog aditiva i njegovog udela u mešavini (otpad/aditivi). Proces S/S nalazi opravdanu primenu kod otpada u tečnom stanju ili otpada sa velikim sadržajem tečne faze, čije odlaganje na deponije bez prethodnog tretmana nije moguće.

Ovi procesi se mogu vršiti in-situ - na lokaciji na kojoj se nalazi opasan otpada i ex-situ - u pogonima koji su projektovani za tu namenu.

Ključne reči: proces stabilizacije/solidifikacije, zaštita životne sredine, opasan otpad, aditivi

\section{UVOD}

Procesi stabilizacije/solidifikacije su u upotrebi od 1950. godine, kada su primenjeni za tretman radioaktivnog i opasnog otpada; danas se ovi procesi i tehnologije koriste za tretman i remedijaciju kontaminiranog zemljišta i otpada koji potiče iz tehnoloških procesa prerade metala, prečišćavanja voda za piće i dr.

Stabilizacija/solidifikacija (S/S) je proces koji se koristi za odstranivanje širokog spektara zagađujućih supstanci iz različitih mate-

rijala i kontaminiranih otpada, posebno onih koji su kontaminirani sa supstancama koje su klasifikovane kao „opasne“. Tretman podrazumeva mešanje vezivnog sredstva sa medijimom ili kontaminiranim otpadom [1].

Tretman podrazumeva mešanje vezivnog sredstva sa medijimom ili kontaminiranim otpadom, na taj način se opasne materije koje se nalaze u njemu imobilizuju i sprečava se njihova mobilizacija u životnu sredinu [2].

\footnotetext{
* Institut za rudarstvo i metalurgiju Bor

** Ovaj rad je rezultat projekta TR 33038 "Usavršavanje tehnologije eksploatacije i prerade rude bakra sa monitoringom životne i radne sredine u RTB-BOR grupa", koji je finansiran od strane Ministarstva prosvete, nauke i tehnološkog razvoja Republike Srbije.
} 
Stabilizacija i solidifikacija su procesi koji obuhvataju širok spektar tehnologija, koje su usko povezane sa hemijskim i/ili fizičkim procesima smanjenja potencijalnih negativnih uticaja na životnu sredinu (zemljište, površinske i podzemne vode) i posredno na živi svet i zdravlje ljudi [2].

\section{POJAM STABILIZACIJE I SOLIDIFIKACIJE}

Stabilizacija se odnosi na tehnike kojima se hemijski postupcima smanjuju potencijalne opasnosti otpada i pretvaraju zagađujuće materije u manje rastvorljive, mobilne, ili toksične oblike. Fizičke karakteristike otpada ne moraju da se menjaju u toku stabilizacije.

Solidifikacija se odnosi na tehnike koje enkapsuliraju otpad, formiraju čvrst materijal, a da pri tome ne mora doći do hemijske interakcije između zagađujuće materije i aditiva koji služe za učvršćivanje. Solidifikacija se postiže hemijskom reakcijom između otpada i određenog reagensa ili meha-

otpada, može biti monolitni blok, materijal sličan glini, granulirane čestice, ili neki drugi drugi fizički oblik koji se obično smatra „čvrstom supstancom“.

Solidifikacija se deli na mikroenkapsulaciju (čestice do $2 \mathrm{~mm}$ ) i makroenkapsulaciju (čestice veće od $2 \mathrm{~mm}$ ) u zavisnosti od granulacije materijala koji se tretira [3]

njenjem površine koja je izložena luženju i/ili oblaganjem otpada sa materjalom male propustljivosti.

Kombinovani procesi solidifikacije/stabilizacije mešanog otpada, zemljišta i mulja, i tretman određenim sredstvima čine opasne sastojke u njima fizički i hemijskim nepo-

eliminišu ili sprečavaju (otežavaju) mobilnost zagađujućih materija [3].

Stabilizacija i solidifikacija su procesi koji obuhvataju širok spektar tehnologija, koje su usko povezane sa hemijskim i/ili fizičkim procesima smanjenja potencijalnih negativnih uticaja na životnu sredinu (zemljište, površinske i podzemne vode) i posredno na živi svet i zdravlje ljudi (ITRC). S/S je važan tehnološki postupak koji omogućava transformaciju otpada u inertni materijal, nezavisno od pojedinačnih vrednosti rastvorljivosti metala, odnosno komponente u otpadu. Takođe je od velike važnosti činjenica da se neki fizički ili hemijski parametari solidifikovanog otpadnog materijala (propustljivost, otpor na kompresiju) mogu lako kontrolisati izborom hemijskog aditiva i njegovog udela u mešavini (otpad/aditivi) [4].

\section{IZBOR PROCESA STABILIZACIJE/SOLIDIFIKACIJE U ZAVISNOSTI OD VRSTE OTPADNOG MATERIJALA}

Izbor procesa pre svega zavisi od vrste otpadnog materijala i njegovog daljeg tretmana. Na osnovu vrste otpada vrši se identifikacija S/S tehnologije kao Best Demonstrated Avialable Treatment Tehnology - BDAT, i na slici 1. prikazane su faze prikupljanja informacija o tehnološkom procesu, a na slici 2. prikazan je način na koji se vrši tehnološka provera procesa stabilizacije/solidifikacije [5].

$\mathrm{Na}$ osnovu preliminarne karakterizacije potrebno je izvršiti uzorkovanje otpada, posle čega je potrebno uraditi dodatnu karakterizaciju na osnovu koje se donosi odluka da li je otpad prihvatljiv za laboratorijska istraživanja ili nije. Ukoliko jeste, vrši se detaljna karakterizacija otpada, zatim fizička, hemijska i mikrostrukturalna ispitivanja $S / S$ otpada, i na osnovu ovih informacija daju se karakteristike pogona, u slučaju S/S ex-situ, slika 1, [5].

Provera tehnologije procesa $\mathrm{S} / \mathrm{S}$ in-situ počinje proučavanjem karakteristika terena i otpada, i uzorkovanjem terena. Nakon toga postavljaju se ciljevi učinka, a zatim je potrebno uraditi fizibiliti studiju u kojoj se odlučuje da li je proces $\mathrm{S} / \mathrm{S}$ održiva opcija. Ukoliko je odgovor negativan potrebno je proveriti da li su izabrana najbolja analitička 
i tehnička rešenja, i ukoliko je odgovor opet negativan, dolazi se do zaključka da bi proces $\mathrm{S} / \mathrm{S}$ bio neuspešan.

Kada fizibiliti studija daje pozitivne rezultate vrši se provera literature za odabir najbolje kombinacije otpad/vezivno sred-

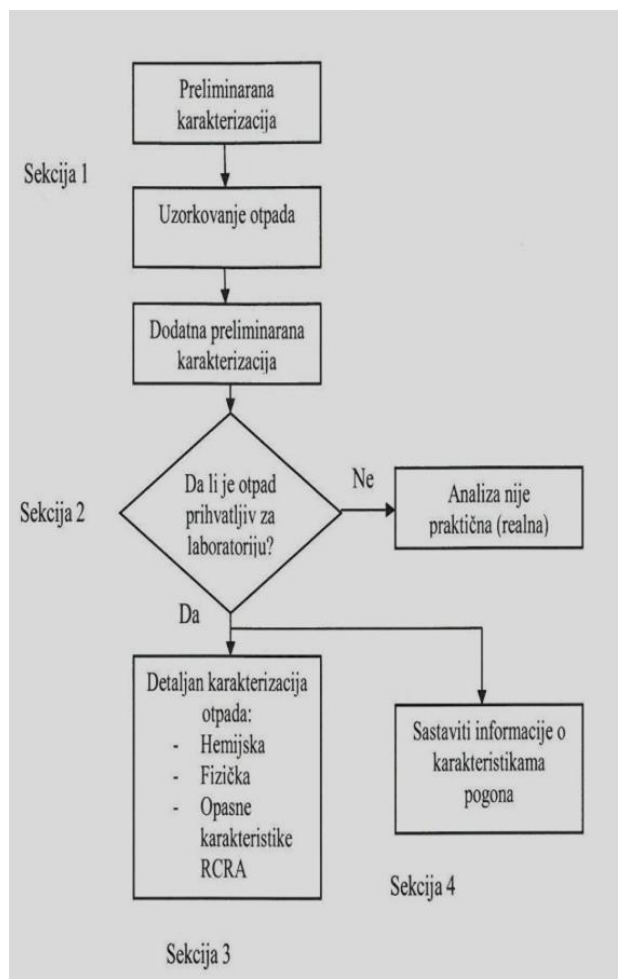

SI. 1. Faze prikupljanja informacija o tehnološkom procesu [5]

\section{IZBOR ADITIVA U ZAVISNOSTI OD VRSTE OTPADA}

Izbor metode $\mathrm{S} / \mathrm{S}$ opasnog otpada zavisi od vrste otpada, sadržaja opasnih i štetnih komponenti, i primenjuje se kao metoda predtretmana opasnog otpada pre odlaganja na deponiju.

Veliki uticaj na efikasnost procesa ima izbor aditiva koji se koriste u procesu $\mathrm{S} / \mathrm{S}$, a koji zavise se od vrste otpada i uslova starenja produkta procesa S/S. Efikasnost $\mathrm{S} / \mathrm{S}$ procesa vrši se određivanjem mobilnosti stvo, i laboratorijska ispitivanja i testiranja U slučaju pozitivnih rezultata vrši se testiranje u pogonu ili pilot postrojenju na osnovu čega se donosi pozitivna ili negativna odluka o procesu S/S otpadnih materijala, slika 2, [5].

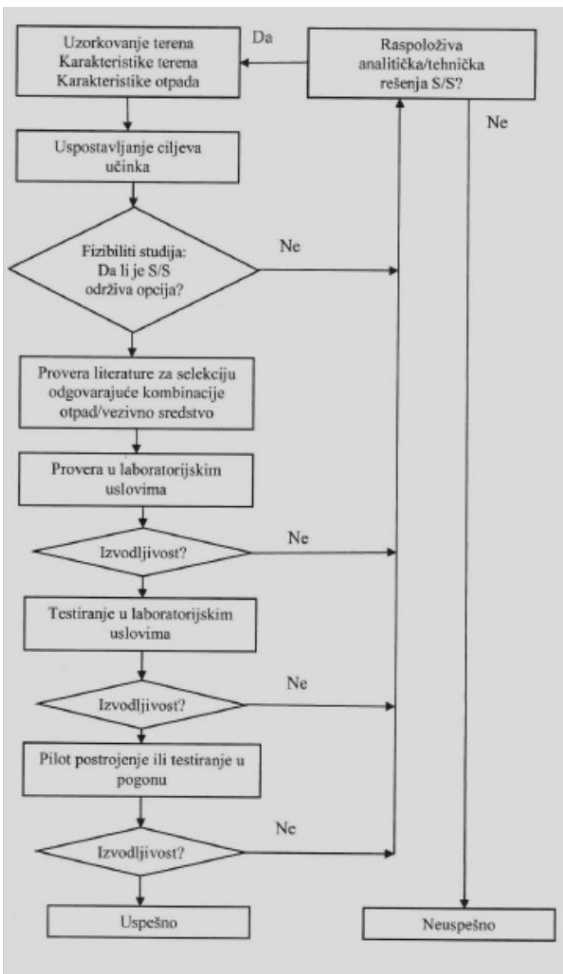

Sl. 2. Provera procesa stabilizacije/solidifikacije [5]

opasnih i štetnih komponenti, i pritisnom čvrstoćom, nakon postupka solidifikacije/stabilizacije.

Aditivi koji se primenjuju kao veziva u procesima S/S mogu biti neorganskog, organskog porekla, ili njihova kombinacija. Najčešće primenjeni aditivi su neorganskog porekla i to: cement, pepeo, kreč, rastvorljivi silikati, pocolani, bentonit, glina, šljaka visokih peći i drugi materijali, a organski aditivi 
su asfalt, epoksid, poliestar i polietilen. U više od $90 \%$ procesa $\mathrm{S} / \mathrm{S}$ koriste se neorganska veziva. U principu, neorganska vezi-

skih. Organska veziva se obično koriste za solidifikaciju radioaktivnog otpada ili specifičnih i opasnih organskih jedinjenja [6].

\subsection{Neorganska vezivna sredstva kao aditivi}

U cilju lakšeg izbora aditiva, u zavisnosti od vrste otpada, u radu autora Fleri $M$. A., $i$ sar., (2007), [7] dat je pregled aditiva koji se koriste u procesima S/S. Na osnovu rezultata dobijenih analitičkim metodama obrade uzorka i kriterijuma koje treba da ispuni $\mathrm{S} / \mathrm{S}$ otpadni materijal vrši se preliminarna selekcija aditiva.

Najčešće korišćen aditiv je portland cement $(P C)$, koji može da zadovolji razne fizičke i hemijske uslove [8]. Tokom testiranja, portland cement se obično kombinuje sa drugim reagensima za formiranje smeše koja zadovoljava potreban kriterijum. Dodaci od primarnog značaja su pocolani, bentonit i hemikalije koje smanjuju luženje i razređivanje zagađujućih materija.

Pocolani su dodaci koji sadrže leteći pepeo, silicijumove pare i druge fino mlevene supstance koje cementu povećavaju čvrstoću, gustinu i izdržljivost. U oblasti zaštite životne sredine najčešće se koriste pocolani koji uključuju leteći pepeo i šljaku iz visoke peći. Pepeo se može podeliti u dve glavne klase, kao što je navedeno u ASTM C618 standardu [9].

Drugi značajan pocolan je šljaka visoke peći, koji se definiše kao „nemetalni proizvod koji se u suštini sastoji od silikata, alumino-silikata kalcijuma i osnove koja se razvija $\mathrm{u}$ istopljenom stanju istovremeno sa gvožđem u visokoj peći.“ Tri vrste šljake se koriste u proizvodnji cementa, i to su vazdušno hlađena, ekspandirana i granulisana šljaka. Osnovna osobina ovih vrsta šljaka je trajnost i upotreba kao dodatak cementnim proizvodima. Zbog svoje pristupačne cene i dostupnosti, šljaka visoke peći je izabrana za upotrebu u smeši sa letećim pepelom [7].

Bentonit je obrađen glineni materijal koji se sastoji uglavnom od minerala montmorilonita. On ima veliki afinitet prema vodi i, kada je hidratisan, povećava svoju zapreminu više od 7 puta [10]. Bubrenje i mala propustljivosti su svojstva zbog kojih je upotreba bentonita široko rasprostranjena $u$ projektima zaštite životne sredine. Smanjenje propustljivosti donjeg dela zemljišta može se postići malim dodacima bentonita; dodavanjem samo $0,75 \%$ bentonita propustljivost se smanjuje dva puta.

\subsection{Efikasnost aditiva za različite vrste otpadnog materijala}

Uspešnost procesa $\mathrm{S} / \mathrm{S}$ pre svega zavisi od izbora aditiva i njihove efikasnosti. U tabeli 1. dati su aditivi koji se najčešće koriste i njihova primena u zavisnosti od vrste otpadnog materijala.

Tabela 1. Preporučene procesi $S / S$ u zavisnosti od vrste otpada [4]

\begin{tabular}{|l|l|}
\hline \multicolumn{1}{|c|}{ Proces S/S } & \multicolumn{1}{c|}{ Primena } \\
\hline Solidifikacija sa cementom & Muljevi, kontaminirana zemljišta \\
\hline Solidifikacija sa krečom & $\begin{array}{l}\text { Otpad od desulfurizacije otpadnih gasova, drugi } \\
\text { neorganski otpad }\end{array}$ \\
\hline $\begin{array}{l}\text { Solidifikacija sa termoplastičnim } \\
\text { materijalima }\end{array}$ & Radioaktivni otpad \\
\hline Inkapsulacija & Muljevi, tečnosti, određene materije \\
\hline Vitrifikacija & Ekstremno opasan otpad, radioaktivni otpad \\
\hline
\end{tabular}

U ovakvim slučajevima efikasna je primena cementa kao aditiva za vezivanje tečne faze, jer cement reaguje sa vodom, hemijski vezujući vodu u hidratisani cementni proizvod. Slobodna tečna faza pri dodavanju cementa vezuje se za njega češće 
hemijskim vezama, a ređe biva adsorbovana, i zbog toga je otpor na kompresiju najmanje 0,34 MPa (50 psi) [4].

U slučaju sprovođenja remedijacije, kao postupka održivosti zemljišta, $\mathrm{S} / \mathrm{S}$ je često jedino rešenje i dostupna tehnologija za remedijaciju velike količine zemljišta kontaminirane teškim metalima, mulja ili taloga. U ovom slučaju kao se preporučuje cement, jer smanjuje mobilnost metalnih jona, formiranjem teško rastvornih hidroksida metala, karbonata ili silikata. U toku procesa S/S dolazi do prelaska metala iz jonskog oblika u mineralnu strukturu i fizičke inkap- sulacije. Takođe, predtretmanom se može smanjiti toksičnost nekih metala promenom valentnog stanja [4].

Primenom kombinovanog postupka stabilizacije i solidifikacije otpada koji sadrži teške metale, u velikoj meri dolazi do transformacije oblika u kome se teški metali nalaze i najčešće prelaze $u$ teško rastvorne hidroksidi u kojima je smanjena mobilnost jona teških metala.

Solidifikacijom se dodatno smanjuje mobilnost teških metala iz novonastalih teško rastvornih oblika, slika 3.

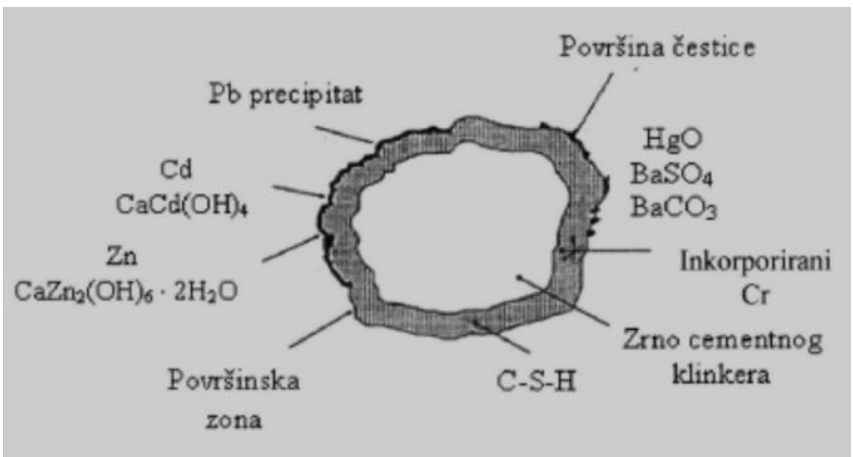

S1. 3. Proizvod procesa stabilizacije i solidifikacije opasnog otpada koji sadrži teške metale, primenom Portland cementa kao aditiva [11].

Tretman materijala koji sadrži pretežno organske zagađujuće materije moguć je takođe primenom cementa kao aditiva. U toku procesa $\mathrm{S} / \mathrm{S}$ dolazi do očvršćavanja materijala, kroz promene fizičkih osobina cementa. Naročito se preporučuje ukoliko otpad ili materijal sadrži slobodnu vodu, koja ulazi u proces hidratacije, stvarajući sa cementom visoko fizički integrisan materijal, monolit. Postupak je pokazao visoku efikasnost u smanjenju mobilnosti opasnih i štetnih materija iz otpada koji sadrži polu i teško isparljive policiklične aromatične ugljovodonike (PAH), polihlorovane bifenile (PCB), pesticide, organske cijanide i dr.

Nedostatak S/S primenom cementa je u slučajevima kada otpad ima visoki sadržaj masti i ulja, kada je onemogućen proces hidratacije cementa. Čestice cementa bivaju obložene uljima ili mastima, čime je onemo- gućen kontakt između cementa i vode. Neke organske komponente utiču na vreme vezivanja cementa, čime ceo postupak solidifikacije može znatno da se produži. Iz navedenih razloga, neophodno je pre izbora aditiva uraditi kompletnu kvalitativnu i kvantitativnu hemijsku analizu otpada, čime se sprečava nastanak neželjenih efekata na samom terenu. Takođe, upotrebom negašenog kreča kao aditiva dolazi do egzotermne reakcije tokom procesa hidratacije, čime se oslobađa znatna količina energije. Ako su u otpadu prisutne lako isparljive opasne i štetne komponente, iste će tokom procesa $\mathrm{S} / \mathrm{S}$ biti emitovane u atmosferu. Ako ne postoji druga alternativa negašenom kreču kao aditivu u procesu $\mathrm{S} / \mathrm{S}$, neophodno je obezbediti uređaje za sakupljanje i tretman gasova/vazduha [4]. 


\subsection{Izbor aditiva u zavisnosti od vrste otpada}

U cilju lakšeg izbora aditiva u zavisnosti od vrste otpada rađena su istraživanja od strane autora Chan B. K. C. i sar. (2008), [14]. Ispitivani materijali za izradu modela za izbor aditiva bili su sledeći: JR - otpad sa najvećim sadržajem opasnih komponenti, OMW - fino granulisani otpad sa niskim sadržajem opasnih kom- ponenti. Testirani aditivi su: SS - kvarcni pesak, PC - komer-cijalno dostupni Portland cement, FA - leteći pepeo i L - kreč. U tabeli 2. prikazani su rezultati ispitivanja stabilizacije opasnog otpada sa različitim sadržajem opasnih komponenti primenom različitih aditiva $i$ sa različitim udelom.

Tabela 2. Rezultati ispitivanja stabilizacije opasnog otpada sa različitim sadržajem opasnih komponenti primenom različitih aditiva [12]

\begin{tabular}{|c|c|c|c|c|c|c|c|}
\hline \multirow{2}{*}{ MEŠAVINA } & \multicolumn{9}{|c|}{ \% Osušenog kontaminiranog zemljišta/otpada } & \multirow{2}{*}{$\begin{array}{c}\text { Udeo } \\
\text { voda/otpad }\end{array}$} \\
\cline { 2 - 7 } & PC & FA & SS & OMW & JR & L & 0,20 \\
\hline 5PC-FA & 5 & 15 & 80 & - & - & - & 0,30 \\
\hline 5PC-FA-OMW & 5 & 15 & 70 & 10 & - & - & 0,25 \\
\hline 5PC-FA-JR & 5 & 15 & 70 & - & 10 & - & 0,30 \\
\hline 10PC-FA-JR & 10 & 15 & 65 & - & 10 & - & 0,43 \\
\hline 10L-FA-JR & - & 15 & 65 & - & 10 & 10 & 0,41 \\
\hline 5PC-FA-L-JR & 5 & 15 & 65 & - & 10 & 5 & \\
\hline
\end{tabular}

$J R$ - otpad sa najvećim sadržajem opasnih komponenti, OMW - fino granulisani otpad sa niskim sadržajem opasnih komponenti, SS - kvarcni pesak, PC - komercijalno dostupni Portland cement, FA - leteći pepeo i $L$ - kreč

Koncentracije teških elemenata As, Cd, $\mathrm{Co}, \mathrm{Cu}, \mathrm{Mn}, \mathrm{Mo}$ i Ni u otpadu posle predtretmana, dobijene sprovođenjem propisanih procedura ispitivanja opasnih i toksičnih karakteristika otpada, bile su ispod granice dozvoljenih vrednosti za podzemne vode i zemljište, čak i iz uzoraka otpada koji ima povećani sadržaj opasnih komponenti. $\mathrm{Na}$ slici 4 su prikazana koncentracije $\mathrm{Pb}$ i $\mathrm{Zn}$ sa različitim aditivima, i sa kojih se vidi da su koncentracija $\mathrm{Pb}$ i $\mathrm{Zn}$ sa kombinacijom aditiva 5PC-5L-JR iznad dozvoljenih granica. U ispitivanom uzorku JR koncentracije $\mathrm{Pb}$ i $\mathrm{Zn}$ su bile iznad dozvoljenih granica. Rezultati ispitivanja kontaminiranog zemljišta sa manjim sadržajem opasnih komponenti, a nakon sprovedenog postupka predtretmana, dali su zadovoljavajuće rezultate [12]. Adsorpcija na hidratisanom gvožđe(III)-oksidu, koji je bio prisutan u uzorcima smanjila je mobilnost jona arsena, slika 5.

\subsection{Pravilan izbor reagensa}

Za stabilizaciju otpada koji sadrži teške metale i veliku količinu vode, a koji je nastao kao posledica rudarskih aktivnosti, postupak koji se preporučuje je neutralizacija krečom iz razloga stvaranja teško rastvornih hidroksida u alkalnim uslovima.

Dodatno, u postupku solidifikacije može nastati po površini zrna, u prisustvu silicijuma i aluminijuma, nepropusna barijera, kalcijum-silikatni gel ili kalcijum-aluminatni gel, čime se povećava efikasnost postupka [13]. Kriva rastvorljivosti hidroksida teških metala u zavisnosti od $\mathrm{pH}$ vrednosti sredine prikazana je na slici 6. (a), čime se jasno uočava uticaj $\mathrm{pH}$ vrednosti na mobilnost teških metala [4]. 

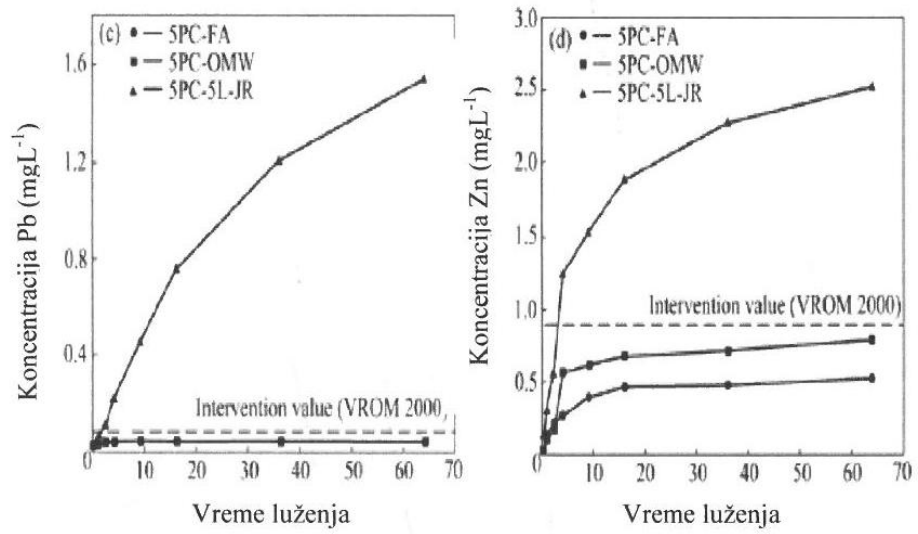

Sl. 4. Koncentracije Pb i As uz dodatak različitih aditiva [12]

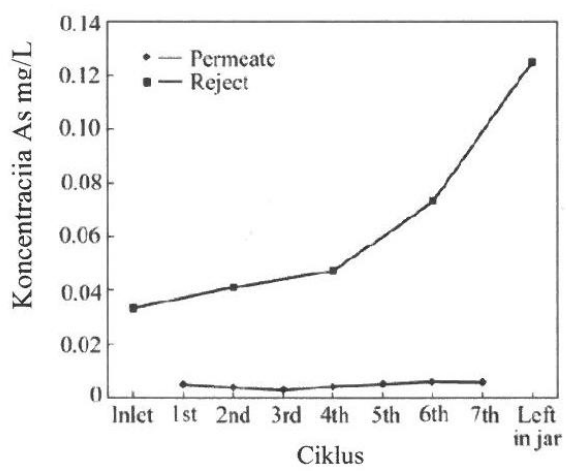

S1. 5. Koncentracija As bez $i$ sa dodatkom aditiva $\left(\mathrm{Fe}_{2} \mathrm{O}_{3}\right) \mathrm{sa}$ početnom koncentracijom As od 0,03 mg/L [12]

Tretman nastalog produkta nakon procesa solidifikacije i stabilizacije otpadnog materijala može imati značajni efekat na efi-

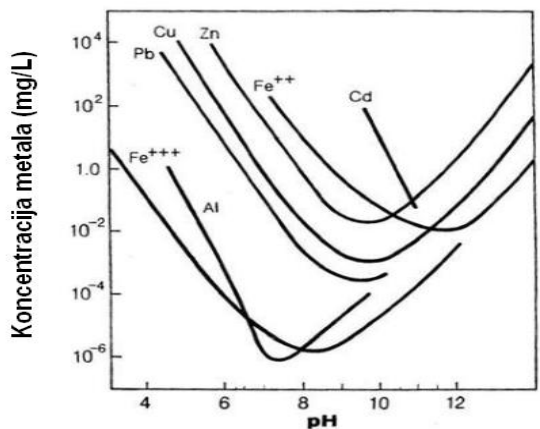

(a) kasnost postupka. Na slici 6. (b) prikazan je uticaj temperature i uslova sušenja i vremena starenja na mobilnost cinkovih jona u mulju.

Sl. 6 (a) Kriva rastvorljivosti hidroksida teških metala u zavisnosti od pH vrednosti $i$ (b) Uticaj temperature, uslova sušenja i vremena starenja na mobilnost cinkovih jona u mulju [4] 
Sa slike 6. se jasno uočava da starenje od 6 meseci pri temperaturi od $25^{\circ} \mathrm{C}$, pri atmosferskim uslovima, smanjuje mobilnost jona cinka na ispod $10 \mathrm{mg} / \mathrm{L}$ [4].

\section{PROCESI \\ STABILIZACIJE/SOLIDIFIKACIJE IN-SITU I EX-SITU}

Procesi i tehnologija stabilizacije/solidifikacije in-situ popularni su za tretman i remedijaciju kontaminiranog zemljišta, posebno na lokaciji na kojoj objekat već postoji ili je napušten. Proces S/S doprinosi održivom razvoju, tako što se kontaminirani materijal može tretirati na licu mesta i na taj način ponovo koristiti, bez potrošnje goriva za transport i smanjenja rizika za okolinu [1].

In-situ stabilizacija/solidifikacija, odnosno dubinsko mešanje zemljišta, je široko prihvaćen tehnika u oblasti zaštite životne sredine, koja se koristi za imobilizaciju zagađujućih materija, čime se sprečava dalje širenje zagađenja kroz zemljište i podzemne vode. S/S se koristi za ekološko tretiranje raznih industrijskih otpadnih materijala na kontaminiranim lokacijama. U svakom slučaju, tretiran materijal može se ponovo upotrebiti na licu mesta ili na drugoj lokaciji, što značajno smanjuje troškove, i štiti zdravlje ljudi i životnu sredinu [1].

Najzastupljenija in-situ proces stabilizacije podrazumeva mešanje kontaminiranog zemljišta ili otpada sa cementom kao aditivom ili drugim materijalima koji imaju slične hemijske i fizičke osobine (leteći pepeo i sl.), koji imaju veliku sposobnost adsorbcije, time smanjuju pokretljivosti opasnih i štetnih komponenti [14].

Procesi S/S koji se koriste za remedijaciju imaju namenu da smanje prolazak zagađujućih materija iz zemljišta, taloga, mulja i otpada koji se ispira (luži) iz izvora zagađenja u okolinu, u okviru prihvatljivih kriterijuma navedenih u cilju remedijacije.

Tehnologija S/S se može primeniti za širok spektar zagađujućih materija. Uspešna primena ove tehnologije počinje ispitivanjem lokacije. Nakon toga, i na osnovu prikupljenih podataka, vrši se izrada tehnoekonomske studije (TS - Treatibility Study) i pilot studije (PS - Pilot Study) iz kojih se vidi potrebna količina i uticaj veziva na zemljište, kao i geohemija zemljišta. Da bi se utvrdila potencijalna efikasnost S/S tehnologije treba prikupiti parametre koji se odnose na testove i kriterijume, koji se koriste za razvoj S/S tretmana koji zadovoljava ciljeve remedijacije. Ove specifikacije imaju za cilj: (1) usmeravanje i procenu fizibiliti studije, i (2) uspostavljanje minimalnog broja operacija na terenu i usklađenost karakteristika materijala u laboratorijskim uslovima. Unapređenje tehnologije - projekta S/S vrši se praćenjem životnog cilkusa procesa, od istraživanja lokacije do potpunog završetka remedijacije, kao dokaz održivosti tehnologije. Dobro urađena fizibiliti studija može smanjiti broj i vrstu aditiva koje je potrebno koristiti u pilot studiji, koja takođe omogućava pravilno određivanje cena, isporuku $\mathrm{i}$ dostupnost aditiva $\mathrm{i}$ vezivnih sredstava, kao i da se bolje razumeju fizičke i hemijske osobine kontaminiranih otpada. Izbor aditiva i veziva mora se vršiti planski, na osnovu fizičkih i hemijskih osobina otpada, zatim na osnovu najboljeg isporučioca aditiva, a i najrasprostranijeg i najisplativijeg vezivnog sredstva, jer troškovi za aditive mogu da iznose 30-50 \% od troškova za stabilizaciju [7].

Kada je remedijacija implementirana realizovana, potrebni su dugoročni programi upravljanja prirodnim resursima koji se obično koriste za proveru da li je projekat i dalje na snazi, i kao takav da li štiti zdravlje ljudi i životnu sredinu (ITRC).

Fleri M. A. i sar.(2007) [7] prikazali su niz projekata u kojima je prikazana tehnologija stabilizacije koji uključuju injektiranje vezivnog sredstva u zemljiste. U stvari, tehnologija dubinskog mešanja zemljišta postaje čest izbor remedijacione tehnologije, slika 7., jer se smanjuje količina iskopanog zemljišta (off-site), i na taj način štede naknade i troškovi uklanjanja i naknadnog popunjavanja; smanjuju se neprijatni mirisi za vreme vršenja sanacije okoline i ukupni remedija- 
cioni troškovi su znatno niži od drugih remedijacijonih tehnologija, kao što termička

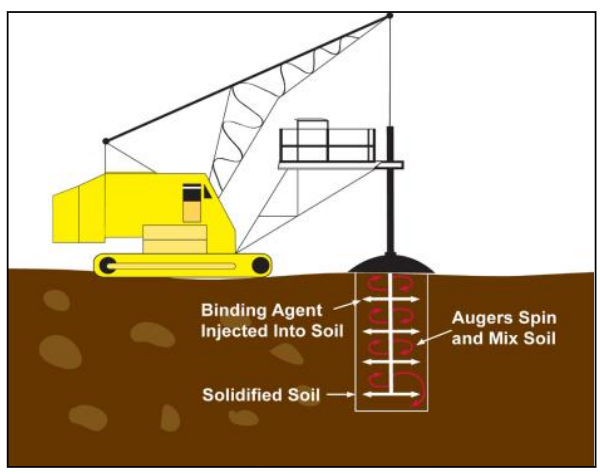

(a) desorpcija i in-situ hemijska oksidacija za otklanjanja kontaminiranih materijala.

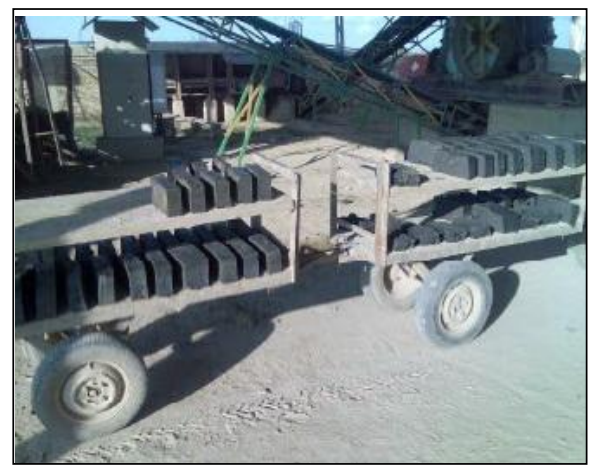

(b)

SI. 7. S/S proces in-situ (a) i ex-situ (S/S otpadni materijal) (b)

Procesi S/S ex-situ se primenjuju u pogonima koji su projektovani za te procese, a koriste se za različite vrste muljeva, i druge otpadne materije koje sadrže „opasne“ supstance, kao što su teški metali, $\mathrm{S} / \mathrm{S}$ otpadni materijal dat je na slici 7 [15].

\section{ZAKLJUČAK}

Za procese stabilizacije/solidifikacije (S/S) je dokazano da su efikasni za tretman otpada koji sadrži opasne materije. Najvažniji korak u procesu $\mathrm{S} / \mathrm{S}$ otpadnog materijala predstavlja kvalitativna i kvantitativna analiza otpadnog materijala, na osnovu koje se može izvršiti izbor vezivnog sredstva i aditiva. Fizičkim i hemijskim metodama vrše se ispitivanja $\mathrm{S} / \mathrm{S}$ proizvoda, na osnovu kojih se vrši njegova kategorizacija.

Promenom fizičkog karaktera otpada primenom procesa stabilizacije/solidifikacije, sprečava se nastanak velike količine procednih voda na deponiji sa visokim sadržajem opasnih i štetnih komponenti; čime se postiže dvostruki efekat, štiti se životna sredina sa jedne strane, a sa druge strane smanjuju se troškovi procesa zbrinjavanja opa- snog otpada, jer nema potrebe za instalacijom i radom sistema za prečišćavanje otpadnih/procednih voda sa deponije.

\section{LITERATURA}

[1] Wilk C. M. (A), Applying Solidification/Stabilization for Sustainable Redevelopment of Contaminated Property [Internet]. LEHP, QEP, LEED AP Program Manager, Waste Treatment Portland Cement Association; http://www.pollutionengineering.com/ ext/resources/PE/Home/Files/PDFs/PC A_S-S_Whitepaper.pdf?1354286601

[2] ITRC, [Internet]. Washington: Interstate Technology \& Regulatory Council, http://www.itrcweb.org/ Team/Public? teamID $=15$

[3] EPA, 1999., [Internet]. Solidification/stabilization resource guide, EPA/542-B-99-002 (1999), http://epa.gov/tio/download/remed/soli dstab.pdf

[4] Zinck J., [Internet]. Canada: Review of Disposal, Repro-Cessing and Reuse Options for Acidic Drainage Treat 
ment Sludge, The Mining Association of Canada, MEND and CENMET Mining and Mineral Scienties Laboratories, MEND Report 3. 42. 3, 2005: 3, http://mend-nedem.org/wp-content/ uploads/2013/01/3.42.3.pdf

[5] EPA 1993., [Internet]. Technical Resource Document, Solidification/Stabilization and its Application to Waste Materials, June 1993, p. 1-5. p. 2-6. (A), p. 2-2. (B)

[6] EPA, 2000., [Internet]. Solidification/ Stabilization Use of Superfund Sites, EPA-542-R-00-010, Septembar 2000, http://www.epa.gov/tio/download/rem ed/ss_sfund.pdf

[7] Fleri M. A., Whetstone G. T., In situ stabilisation/solidification: Project lifecycle, J. Hazard. Mater. 2007; 141: 441-456.

[8] ASTM C150, Standard Specification for Portland Cement, vol. 4.01, American Society for Testing Materials, West Conshohocken, Pennsylvania, 2003, pp. 150- 153.

[9] ASTM C618, Standard Test Method for Coal Fly Ash and Raw or Calcined Natural Pozzolan for Use in Concrete, vol. 4.02, American Society for Testing Materials, West Conshohocken, Pennsylvania, 2003, pp. 319-321.

[10] Black Hills Bentonite, LLC. 2009. [Internet]. Wyoming, http://www.bhbentonite.com/minchar. htm
[11] Ganjidoust H., Hassani A., Rajabpour Ashkiki, Cement-Based Solidification/Stabilization of Heavy Metal Contaminated Soils with the Objective of Achieving High Compressive Strength for the Final Matrix, Sharif University of Technology, Transaction A: Civil Engineering, 2009; 16: 107-115, http://www.sid.ir/en/VEWSSID/J_pdf/ 95520092A05.pdf

[12] Chan B. K. C., Bouzalakos S., Dudeney A. W. L., Integrated Waste and Water Management in Mining and Metallurgical Industries, Trans. Nonferrous Met. Soc. China. 2008; 18: 1497-1505

[13] Bakstrom M. Baltic Sea Region Programe, Orebro University, Sweden: Compendium of Mining and Processing Waste Management Technologies, Project: MINNOVATION Mining and Mineral Processing Waste Management Innovation Network, Baltic Sea Region Programe, 2013: 214, http://www.minnovation.eu/uploads/ compendium $\% 20$ of $\% 20$ Mining $\% 20$ and $\% 20$ Processing\%20Waste $\% 20 \mathrm{Man}$ agement\%20Technologies.pdf

[14] Gardić V., Obradović Lj., Filipović S. Review of Solidification and Stabilization Methods of Hazardous Waste, MME Bor. 2013; 4: 93-100.

[15] Krčmar D., Stabilizacija/solidifikacija mulja bogatog arsenom. http://www.arsenicplatform.pmf.uns.ac .rs/pdf/10_Solidifikacija.pdf 